\title{
A Micro-Ethnographic Approach: Investigating Classroom Teachers' Knowledge of Students with Special Needs
}

\author{
Julie Lamb-Milligan, Gwen Neal \\ College of Education \& Behavioral Science, Arkansas State University, Jonesboro, AR, United States
}

Email address:

jlamb@astate.edu (J. Lamb-Milligan), gneal@astate.edu (G. Neal)

\section{To cite this article:}

Julie Lamb-Milligan, Gwen Neal. A Micro-Ethnographic Approach: Investigating Classroom Teachers' Knowledge of Students with Special Needs. Psychology and Behavioral Sciences. Vol. 9, No. 1, 2020, pp. 1-5. doi: 10.11648/j.pbs.20200901.11

Received: November 19, 2019; Accepted: January 31, 2020; Published: February 28, 2020

\begin{abstract}
Classroom teachers are vital stakeholders in the ultimate success of programs for children with special needs. These teachers are responsible for recognizing individual learning needs and referring those students for services. In most instances, classroom teachers are responsible for assisting specialists with planning and making modifications in the regular classroom to accommodate the learning needs of diverse learners. This manuscript addresses concerns related to the lack of classroom teachers' knowledge regarding learning disabilities and giftedness when there is a lack of training and support offered to them. It also addresses many positive effects and results when classroom teachers are involved in staff development and collaborative efforts which heighten their awareness and knowledge of special needs. Educating classroom teachers, regarding special education or gifted education, is the responsibility of administrators or specialists who oversee programs. This review of literature and use of micro-ethnographic methodology to examine 59 classroom teacher interviews provides evidence and suggestions for raising awareness among specialists in gifted and special education as they prepare to assist other educators with referrals and accommodations for children with diverse learning needs.
\end{abstract}

Keywords: Gifted, Inservice, Perceptions of Classroom Teachers, Referral, Special Services, Staff Development

\section{Introduction}

Classroom teachers play an important role in the success of gifted programs. During the past decade, researchers [2, 3, 14] consistently reported more support from classroom teachers for children in need of special programming when the teachers had a greater understanding of diverse learning needs. On the other hand, when classroom teachers were unaware of characteristics and appropriate program services, the chance for successful cooperation in matters of identification and services greatly diminished [4, 15].

When programs for advanced learners were being initiated in many states in the US in the 1980s, some programs struggled to survive due to the negative results of classroom teachers' knowledge of giftedness [7, 16]. Specifically, the lack of program success was noted when classroom teachers were selected to provide services for the gifted through enrichment and acceleration strategies but had no knowledge or ownership in the process. The reason for their selection, given by the administrators, was because those teachers were creative, young, and or "gung ho". One teacher reported, "I knew nothing. I had no preparation. Nobody sent me anywhere. Nobody gave me any clues" [16, p. 35]. According to those same classroom teachers, the school district was unable to maintain a program for advanced learners due to their lack of teacher preparation and knowledge about diverse learning needs and modifications. Professionals might assume progress has been made since those early times. However, professional literature indicates a lack of knowledge and support by classroom teachers for programs serving diverse learning needs $[4,5,14]$ may still exist.

Specifically, classroom teachers have described problems with gifted programming in the following areas: (a) disruptions related to gifted students being pulled from class for program services, (b) conflicts that existed in opinions about the definition of giftedness, (c) complaints by teachers and students that program participants behaved arrogantly, and (d) complaints by teachers and parents that tracking was detrimental to lower performing students [14]. Such negative feelings might negatively impact the referral process, placement and services of children with diverse learning 
needs.

It was the implementation of more inclusive classrooms, when children of all abilities began being served in the regular classroom the majority of the school day, that classroom teachers' knowledge about diverse learning needs (i.e., learning deficits or advanced learning needs) became essential. Thus, the need for teacher training and collaborative efforts became necessary. In essence, mainstreaming required a new philosophy which brought about teams of general education and special education teachers. Ripley [13] described the foundation of successful collaboration in terms of improving professional knowledge. According to Ripley [13], professional knowledge come about in the form of effective goal setting, sound classroom instruction, joint responsibility for students, team assessment of student learning, problem solving, and classroom management.

An effective team works together as equal partners in interactive relationships, with both involved

in all aspects of planning, teaching, and assessment. Noted by Miller and Oh [8], five planning themes were identified by co-teachers who considered themselves to be effective coplanners. These included 1) confidence in partner's skills, 2) design of learning environments for both the educators and students that require active involvement, 3) creation of learning and teaching environments in which each person's contributions are valued, 4) development of effective routines to facilitate in-depth planning and 5) increased productivity, creativity, and collaboration over time. Participants in collaborative programs agreed that the time required for planning does not decrease during the year, but the quality of instruction continues to improve.

In a study conducted by Milligan and Campbell [11], teachers of a summer program for gifted

students reported the positive effects of communication and co-teaching with other teachers. These teachers said that as they cohabited and did team-teaching, a sense of camaraderie and security developed. They also said that sharing ideas during planning made the co-teaching more than just the shared teaching of a lesson. The experience became a source of shared decision-making and professional growth.

An important conclusion may be drawn from research $[8$, 11, 13, 14]. Classroom teachers' understanding of special education and gifted education is vital in successful programming for these learning who have different learning needs from their age peers. Further, teacher's involvement in curriculum planning for gifted children is important to the success of gifted programs. Promising practices for classroom teachers and successful gifted and special education begins with cooperation between the special educator and the classroom teacher.

\section{Method}

A micro-ethnographic approach was used in this research. By design, one specific group or subpopulation was included - classroom teachers. The group consisted of 59 teachers who had no prior training in gifted education. Interviews were conducted over the course of two academic years; teachers, who were candidates for a master's degree in gifted education, conducted interviews. The purpose of this activity was to assess and compare the classroom teachers' knowledge of (a) characteristics of giftedness, (b) identification procedures for their school district and (c) strategies for differentiating curriculum for the gifted. In the analysis, themes emerged regarding predominant perceptions. The purpose of the analysis of these interviews was to determine if the 59 classroom teachers' perceptions of students with diverse learning needs aligned with previous research that indicated the need for training in preservice education programs or inservice training for practicing teachers. Based on conclusions from previous research [3, 14] without such training to enhance knowledge, accurate identification and support for programs may be at risk.

\subsection{Micro-Ethnographic Analysis}

From 59 classroom teacher interviews, the analysis revealed that in the category of characteristics of giftedness, $89 \%$ of the classroom teachers interviewed reported that gifted students are those who make all A's, are highly motivated, are self-directed, and are outgoing. While this does fit the profile or many gifted children, not all gifted children are the perfect student $[6,18]$. Our expressed desire is that students, who are cognitively and creatively gifted, perform at an exceptional rate academically. But using grades and academic performance exclusively as an indicator of giftedness becomes problematic for those students who are underachievers, twice exceptional or highly creative and lack the desire to conform.

A closer examination of eminent adults such as Sir Issac Newton, who "was a failure throughout much of his school career and considered to be an idle tinkerer until he formulated the Laws of Gravity" [15], has required educators to reevaluate the validity of IQ scores and academic achievement alone to determine human intellectual potential or ability. Miller [9] also noted that hidden characteristics might exist in individuals with exceptional intellectual and creative potential by stating:

The list of universally recognized talented people whose gifts were not identified by the professionals in their youth is distressingly long. Winston Churchill, Thomas Edison, Albert Einstein, Emily Dickinson...to name but a few examples, were consistently undistinguished by the professional of their time. p. 6 .

Another theme emerged among the 59 classroom teacher interviews. The teachers who used creativity as an indicator of giftedness, linked creativity to visual arts. When asked how they determined if students in their classrooms were exceptionally creative, they referenced drawing as the primary indicator. In other words, when students were artistically talented, they were labeled highly creative.

In both of these scenarios (i.e., narrow views related to 
academics and creativity), the need for systematic professional development is noted. Consequently, when classroom teachers use excellent grades they may overlook cognitive processing. And when teachers limit creativity to visual arts, there is the possibility of oversight in regard to students who are creative problem solvers or nonconformist to regiment based on his or her desire to think and act differently from peers.

\subsection{Referral and Identification Procedures}

Educators of the gifted may assume that classroom teachers understand the identification process. However, educators tend to know what they experience. In the interviews of 59 classroom teachers, fifteen percent reported understanding the identification procedures. Of all the teachers interviewed those who understood kinds of assessment tools used to measure potential and ability had previously served on identification committees. Further, those same teachers were the ones who knew what kinds of criteria were used to place students in the program for the gifted.

How should teachers know about assessment tools or placement procedures lest educators of the gifted instruct them regarding the process? Further, classroom teachers must be educated in both traditional standardized methods and performance-based methods. The use of standardized test scores to determine giftedness has been labeled traditional assessment [3, 9]. For approximately half a century from the 1920 's to 1980 's, traditional assessment was the predominant determinant of giftedness in schools. It has only been within the past twenty years that researchers and educators have questioned the use of IQ to determine intellect or the sole use of IQ to determine giftedness. With expanded definitions of intelligence, expanded definitions of giftedness emerged. Within the more current theories, a performance-based identification philosophy is apparent. A performance-based assessment for determining giftedness includes observation by trained specialists to recognize certain student actions as 'above average' and/or the examination of students' products as exemplary or exceptional.

In 2013, Pfeiffer [12] did a survey of 64 experts in the field of gifted education. He asked them about the three greatest identification, assessment, and/or definitional issues in gifted education. Interestingly, all of their responses emphasized the shift from traditional to a more performancebased view of giftedness. With this shift and as gains are made in the use of performance-based guidelines as a viable option for assessing giftedness, classroom teachers are our greatest asset. They are with the students the majority of the school day and should be instrumental in observing students' behaviors in terms of potential giftedness. The need for professional development should be noted. When preservice programs do not require preservice teachers to engage in coursework, field activities or seminars regarding identification and assessment matters, then professional training through inservice is necessary.

\subsection{Curriculum Used in Programs for the Gifted}

In the interviews with classroom teachers, only $8 \%$ reported awareness of the GT Frameworks used by the facilitator of the gifted for program planning and services. Approximately $12 \%$ reported the use of some varied or different teaching strategies for those who were identified as gifted, talented, or creative.

These statistics are especially disconcerting when we consider the benefits of cooperative efforts between classroom teachers and educators of the gifted. When programs are structured with pull-out program options, the teacher of the gifted may have the students for three hours per week. The rest of the academic day, the gifted receive academic instruction from the classroom teacher. This alone is cause for us to make curriculum options, geared toward gifted learners, available to classroom teachers.

\section{Conclusions Drawn from Interviews}

From the interview results with classroom teachers in this report, some conclusions may be drawn. First, most classroom teachers used academic success as a key factor in determining which children might be gifted. While this may be an indication of giftedness, it is just as important that classroom teachers understand that many highly intelligent and creative children find school boring, uninteresting, or unnecessary and do not perform well academically. Services for these children are just, if not more, important than for those who are more compliant to the curriculum and routines of schools.

Secondly, classroom teachers were more aware of identification procedures when they had been involved in the selection process. It might be noted that a good policy is to have teachers, serving on the identification committee, rotate frequently so that more teachers have the experience of review student profiles for decisions about placement.

Thirdly, classroom teachers were rarely aware of curriculum required, mandated or delivered to gifted children. A good practice for specialists is to provide copies of goals, objectives, and frameworks for gifted education to classroom teachers. Educators of the gifted might also correlate activities for the gifted, which cover both gifted education frameworks and classroom skills. In turn classroom teachers might be invited to assist with periodic reviews of frameworks used in the program for the gifted and make suggestions for bettering standards and services. Another advisable practice is make training available to classroom teachers in differentiated strategies they might incorporate into their curriculum.

\subsection{Educating Classroom Teachers Through Staff Development}

Researchers [1] reported the positive impact of professional development on classroom teachers' awareness of curriculum appropriate for gifted learners. A cohort of preservice teachers were assessed prior to a practicum. 
Interviews, classroom observations, and lesson planning were used to evaluate the preservice teachers' understanding of appropriate curriculum for the gifted. At the end of the practicum, it was reported that an increased level of knowledge and preparation improved their comfort level and confidence to identify and teach the gifted in their future classrooms.

The results of a study by Milligan [10] revealed that each teacher at one elementary school in grades K-4 changed something about the way she defined giftedness following a year-long systematic plan for staff development related to giftedness. In conjunction, each teacher increased the numbers of students she nominated for assessment following staff development. The staff development included demonstration lessons presented by the facilitator of gifted children and four formal inservice sessions presented by a variety of speakers.

Apparent from the wealth of research available, knowing which students to recommend for assessment toward identification of giftedness and how to accommodate their learning needs is based on a teacher's knowledge about giftedness. In both regards teachers' knowledge about giftedness may be enhanced through staff development. Staff development, as a global plan with a specific process, should be very comprehensive including: (a) inservice training to expand knowledge and increase teacher effectiveness; (b) organization planning to improve programming and solve problems; (c) consultation in the form of workshops, inservice, clinics, and special projects. (d) provisions for resources, coordination, and assistance with inter-building communications; (e) assistance with researching, implementing, and evaluating new practices and procedures; and (f) evaluation of staff development efforts and organizing feedback.
Educators of gifted children have an obligation to offer staff development sessions which inform teachers of (a) the characteristics of giftedness, (b) the assessment procedures, (c) the identification process, (d) appropriate curriculum and (e) program options. For staff development, GTC teachers or specialists have an obligation to model to classroom teachers' multiple ways to serve gifted children in the classroom also.

Inservice training, as one component of staff development, has been an established tradition in the education profession; thousands of documents about the most and least effective types of inservice have been written. Related literature distinguished inservice training as it pertained to skills taught in the regular classroom and curriculum for gifted children. Tomlinson [17] reported that teachers who attended inservice training about giftedness preferred (a) active participation in the discussion, (b) handouts with activities to use in their classrooms, (c) visuals to explain information, and (d) techniques for implementing ideas and materials. The least effective types of inservice were lecture, sessions with equipment problems, and occasions when there was personal dislike for the speaker's attitude about gifted education.

To reiterate, who is responsible for educating classroom teachers about the assessment of giftedness and appropriate services through staff development? The specialist for gifted education is responsible. In the spirit of cooperation, each specialist should be obligated to providing effective and productive staff development, including inservice training, to classroom teachers.

\subsection{Suggestions for Telling Others About Giftedness}

There are several strategies that may be implemented to make staff development with classroom teachers conducive for all involved. Suggestions are illustrated in Figure 1.

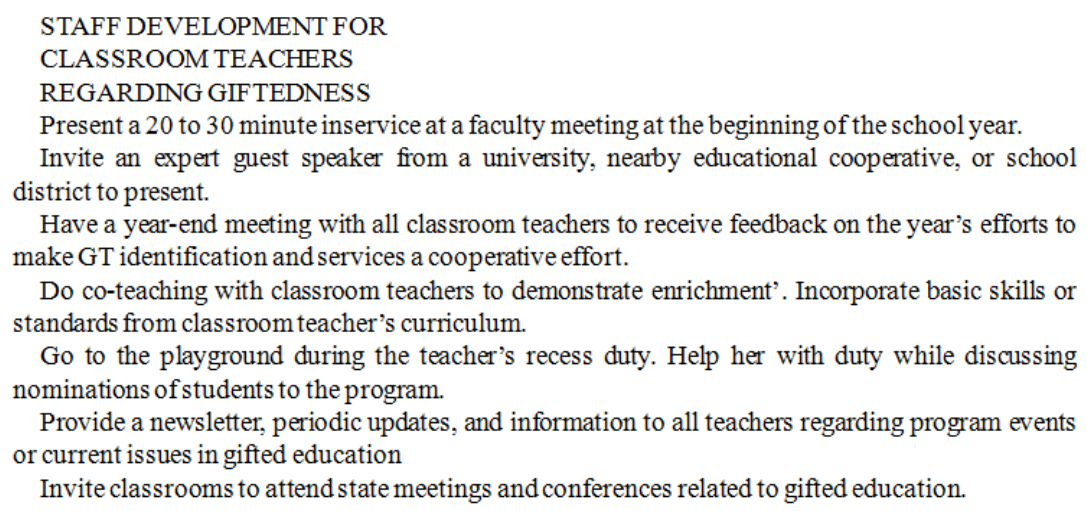

Figure 1. Informing Classroom Teachers About Identification of Giftedness.

As important as having an overall plan for staff development, educators of the gifted may take every opportunity to provide brief inservice sessions at faculty gatherings. Suggestions for presenting effective inservice sessions during brief meetings include: (a) Make it interactive; (b) be concise; (c) let classroom teachers draw some conclusions after effective practice; (d) let them know you are always looking for suggestions; (e) and leave them in the spirit of cooperation. Specifically, make it interactive by perhaps beginning the session with an activity that allows the participants a couple of minutes to work in groups listing characteristics of giftedness. Then have them share their answers around the room until all the ideas have been stated. Be concise with the information. Extensive information about 
administration guidelines, scoring procedures or statistical information about the identification procedure is unnecessary. Let them draw some conclusions by asking them if they feel students in their classroom have been accurately identified. Let them know you welcome their suggestions for ways to identify giftedness. Leave time at the end of the presentation to take their questions. And leave them in the spirit of cooperation by telling them to call you for assistance. Figure 2 illustrates ways to make the information at the inservice session lasting.

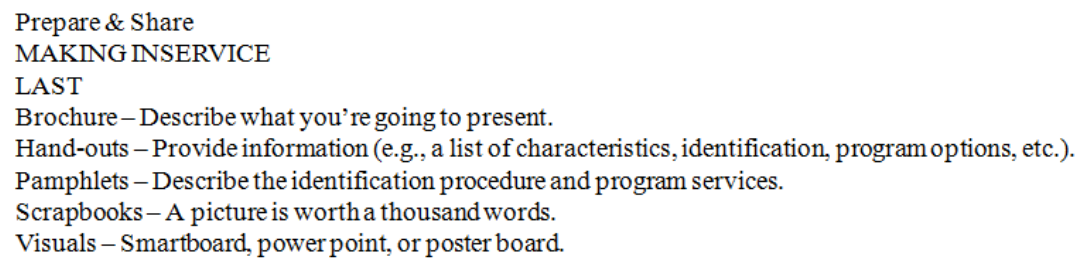

Figure 2. Making A Lasting Impression.

In summary, staff development for classroom teachers about giftedness can occur in several forms. Informally, teachers of the gifted may discuss assessment procedures and prospective referral of students. Teachers of the gifted may offer staff development by conducting demonstration lessons while classroom teachers document potential giftedness. Formal staff development may occur in the form of staff development sessions which provide information and issues related to giftedness. Further, it is the responsibility of the teacher or administrator of the gifted to provide this training to classroom teacher.

The teacher or administrator of the gifted is responsible for building good public relations. It may be one of the most important roles a facilitator or administrator of gifted students plays. The more classroom teachers feel comfortable working as a team as a result of effective public relations and the more teachers know as a result of effective teacher training, the better the chance that accurate identification and services will occur. Working together with classroom teachers will increase the chance of better serving gifted children.

\section{References}

[1] Bangel, N. J., Enersen, D., Capobianco, B., \& Moon, S. M. (2006). Professional development of preservice teachers: Teaching in the super Saturday program. Journal for the Education of the Gifted. 29 (3), 339-361.

[2] Carman, C. A. (2011). Stereotypes of giftedness in current and future educators. Journal for the Education of the Gifted, 34, $790-812$.

[3] Coleman, L. J. (2014). Being a teacher: Emotions and optimal experience while teaching gifted children. Journal for the Education of the Gifted, 37, 56-69.

[4] de Wet, C. F., Gubbins, E. J. (2011). Teachers' beliefs about culturally, linguistically, and economically diverse gifted students: A quantitative study. Roeper Review, 33, 97-108.

[5] Geake, J. G., \& Gross, M. (2008). Teachers' negative affect toward academically gifted students: An evolutionary psychological study. Gifted Child Quarterly, 52, 217-231.

[6] Hertzog, C., \& Robinson, A. E. (2005). Metacognition and intelligence. In O. Wilhelm \& R. W. Engle (Eds.) Understanding and measuring intelligence. London: Sage, 101-123. Hertzog, 2005.

[7] Hickey, M. G. (1990). Classroom teachers' concerns and recommendations for improvement of gifted programs, Roeper Review, 12 (4), 265-267.

[8] Miller, C., \& Oh, K. (2013). The effects of professional development on co-teaching for special education and general education teachers and students. Journal of Special Education Apprenticeship, 2 (1), 1-17.

[9] Miller, E. M. (2009). The effect of training in gifted education on elementary classroom teachers' theory-based reasoning about the concept of giftedness. Journal for the Education of the Gifted, 33, 65-105.

[10] Milligan, J. (2010). Effective staff development in a low socio-economic rural setting: A micro-ethnography of teacher's perceptions of giftedness: (ERIC Document Reproduction Service No. ED 450 992).

[11] Milligan, J., \& Campbell, D. (2003). It's a fit: Collaboration and gifted education. Understanding Our Gifted, 15 (3), 1821 .

[12] Pfeiffer, S. I. (2013). Challenges and opportunities for students who are gifted: What the experts say. The Gifted Child Quarterly, 47 (2) p. 161-166.

[13] Ripley, S. (2019). Collaboration between general and special education teachers. ERIC Digest ED 4093171997.

[14] Russell, J. L. (2018). High school teachers' perceptions of giftedness, gifted education, and talent development. https://doi.org/10.1177/1932202X18775658.

[15] Smutny, J. F., \& Blocksom, R. H. (1990). Education of the gifted. Bloomington, IN: Phi Delta Kappa Educational Foundation.

[16] Starko, A. J. (1990). Life and death of a gifted program: Lessons not yet learned. Roeper Review, 13 (1), 33-38.

[17] Tomlinson, C. (2001). Differentiated instruction in the regular classroom: What does it mean? How does it look? Understanding Our Gifted, 14 (1), 3-6.

[18] VanTassel-Baska, (2006) Serving Gifted Learners Beyond the Traditional Classroom: A Guide to Alternative Programs and Services, Prufrock Press, Waco, TX. 